\title{
Corporate Environmental Accounting: the issue, its practices and challenges: A study on Indian corporate accounting practices.
}

\author{
Dr. Manoj Goswami. \\ Tinsukia College, Tinsukia.Assam
}

\begin{abstract}
Environment is becoming a much more urgent economic, social and political problem all over the world. World is facing the twin problem of promoting economic development and protecting the environment. In this juncture the proper accounting of environmental effects on economic development is pre-requisite to have a sustainable development. It is observed that many efforts have been done to develop a mechanism of incorporating environmental data with national income to compute economic development. Moreover, all such attempts do not address the micro economic aspect of environmental data as such interaction between a specific firm and environment. The accounting of interaction between firm and environment is a pre-requisite to find out sustainability gap in micro level. This study attempts to address the development of corporate level environmental accounting and the problems associated with that. The study is under taken considering the environmental accounting and reporting adopted by sample companies in India .
\end{abstract}

Key word: Environment, Accounting and reporting, environmental cost, liability and Assets

\section{Introduction:}

Climatic change is one of the greatest challenges that world is facing today. Climatic change is the variation in the earth's global climate over the time. This variation may be due to dynamic process on the earth and some of the external influences. The climatic change create manifold problems like global warming, glacier meltdown, soil erosion, land degradation, deforestation, loss of biodiversity and all kinds of pollution. Human influence on the nature is one of the major causes of such problems. Indiscriminate use of resource and undue influence on nature in name of development can be identified as prime causes of this climatic change. As a result, since last few decades the adverse environmental effect of economic development has become a public concern all over the world.

The issue had been repeatedly discussed in a series of international summits right from the sixties. Between 1968 and 1972, two international conferences held to assess the problems of global environment and to suggest corrective action. The UN conference on human and environment (Stockholm conference) which was held in June, 1972, was considered as the pivotal event in the growth of the global environment movement. It was the first occasion on which the political, social and economic problems of the global environment were discussed at an inter-governmental forum with a view to taking corrective action. It aimed at creating a basis for comprehensive consideration with the United Nations on the problems of the human environment and focusing the attention of governments and public opinion to various countries on the importance of problem. United Nation has also made an attempt by developing Integrated System of Environmental economic Accounting (SEEA), a Central multi-purpose conceptual framework that describes accounting of interactions between the economy and environment, and the stocks and changes in stocks of environmental assets. Many countries try to incorporate environmental accounting data with national income to compute economic development. Moreover, all such attempt does not address the micro economic aspect of environmental data as such interaction between a specific firm and environment. The accounting of interaction between firm and environment is a pre-requisite to find out sustainability gap. It is a recognised fact that most of the activities of the economic development have unfavourably affected the environment. As corporate bodies are the major contributors of the economic growth the role of corporate bodies in environmental degradation is also comparatively high. It is often seen that such bodies always try to maximise profit. As a result in the recent time there is a growing tendency among the corporate stakeholders to know environmental effects of business. Considering present state of environmental destruction civil society is increasingly demanding that business should play a pro-active role in societal and environmental objectives in addition to increase in shareholder wealth. This makes environmental accounting and disclosure system paramount important for accounting discipline. It is expected that accountant should play a proactive role to recognise effects on environment of business activity to have a control over sustainability gap. It has been noticed that environmental accounting in macro level as well as in micro level is gaining its importance. In macro level National environmental Accounting focuses on accounting of natural resources stocks \& flows, environmental costs \& externality costs etc. In micro level corporate environmental accounting tries to account for environmental impact on corporate activities. The practice of corporate level environmental accounting has been growing during the few decades 
around the globe. However, the existing environmental and social accounting literature like Harte and Owen (1991), Bewley and Li (2000), Ahmed and Sulaiman (2004), Thomson and Zakarai (2004) Halil Emre Akbas \& Seda Canikli(2014),) identified that still environmental reporting is very low and mere narrative disclosure. Such information were scattered all over the annual report instead of in a specific section.

In India also corporate bodies are increasingly disclosing environmental reporting in their annual report. In a study Paul and Pal (2001), on the basis examination of environmental reporting practices, concludes that it has gained momentum with the passage of time even in the absence of any compulsion and standard guidelines. Chatterjee and Mir (2008) examined the status of environmental disclosure made by top 45 Indian companies in terms of market capitalization and concluded that most of the information disclosed by the sampled firms was narrative. Similarly, Sen (2011) examined the nature and extent of the environmental disclosure practices of Indian core sector companies and found that information disclosed was more qualitative than quantitative and varied across industries as well as companies. Some other studies like Gautam and Bora, Kumar p, Eresi etc. also concluded that environmental disclosures used by Indian companies are only descriptive in nature and not very useful for decision making purpose. On the basis of study on environmental accounting and reporting policy of ONGC and BPCL Shukla \&,Vyas (2013) concluded that commitment that companies shows in the narrative disclosures for environment protection through environmental reporting were not transformed in accounting practices and it lacks quantitative information.

The existing literature on environmental accounting gives enough evidence that though environmental accounting and reporting has gaining momentum but it is not developed as it is desired by stakeholder. Therefore, it is important to find out the challenges faced in sound development of environment accounting and reporting practices.

\section{Objectives of the study:}

The objectives of the study can be highlighted in the following issues:

1. To identify the development of the corporate environmental accounting and reporting.

2. To highlight the corporate accounting and reporting practices in this regards.

3. To find out the major obstacles in the sound development of that practice.

\section{Methodology:}

The study is based on both primary and secondary data. The primary data for the study is the existing environmental accounting and reporting practices of the corporate entities in India. For such data annual reports of twelve (12) sample companies have been consulted for financial year 2012-13. These companies have been selected from the list of top 50 companies of National Stock Exchange. Purposive sampling method has been used to select sample unit and due care have been taken to select companies having presence in the sectors like power, cement, and pharmaceutical sectors as they considered comparatively highly polluted. Out of companies selected as sample unit four (4) companies belongs to cement industry, five (5) companies from energy industry and three (3) companies from pharmaceuticals industries. To have guidelines on environmental accounting and reporting various books and journals have been consulted as secondary source. The study is divided in three parts. Part one discusses the existing guidelines on environment accounting and reporting. Second part deals with the corporate accounting practices and last part is the challenges faced by accountant in the sound development of the issue.

\section{The existing development of environmental accounting:}

Gradually, environment is becoming a much more urgent economic, social and political problem all over the world. World is facing the twin problem of promoting economic development and protecting the environment. It makes the urgent need for balance between development and environmental protection. As a result a careful assessment of the benefits and costs of environmental damages is necessary to find the tolerance limit of environmental degradation and the required level of development. But without having the proper accounting framework, both in the firm level (micro) and in the Government level (macro), it next to impossible to determine whether anybody have been fulfilling their responsibilities towards the environment. "United States Environmental Protection Agency", has mentioned that an important function of environmental accounting is to bring environmental costs to the attention of corporate stakeholders who may be able and motivate to identify ways of reducing or avoiding those costs, while at the same time, improving the environmental quality. The implementation of environmental accounting can help to achieve the objective of corporations and other stakeholders in reducing the costs and decreasing the pollution respectively.

Environmental Accounting may be defined as the process of identification, measurement and allocation of environmental costs, the interaction of these costs into business, identifying environmental liabilities if any and finally communicating these information to stakeholder as a part of general purpose financial statement. It is 
fruitful attempt to identify and bring to light the resource exhausted and cost rendered reciprocally to the environment by business house (pramanik, shil \& das).

In the environmental accounting guidelines (2005) Ministry of Environment, Japan, mentioned that Environmental accounting is a procedure that allows a company to identify the cost of environmental conservation during the normal course of business, identify benefit gained from such activities, provide the best possible means of quantitative measurement (in monetary value or physical units) and support the communication of its results.

Environmental accounting means reporting of environment specific cost such as liability cost and waste disposal costs. It is accounting for any costs and benefits that arise from change to a firm's products and processes where the change also involves a change in environmental impact (Gupta and Mehra). It is a process that permits to internalise all external environmental cost within the ambits of accounting rules and methodology. It requires due recognition of environmental cost in conventional accounting, capital investment decisions, process/product design decisions, cost determination, and other forward looking business decisions. In this regard the major accounting issue is the distinction between environmental expenditure and normal business expenditure, Capitalisation of environmental expenditure vis-a-vis expensesing them during the current accounting period, recognition of environment related contingent liability, and reporting of such to the external users. Therefore, to have uniformity in accounting and disclosure of environmental cost some specific accounting guidelines is required. The most significant development in the environmental reporting within the conventional financial reporting has come from United Nations Commission on Transnational Corporations, Intergovernmental Working Group of Experts on International Standards of Accounting and Reporting (UN CTC IASR). The Ninth Session of UN CTC IASR (1991) made detailed recommendations as to the types of environmental disclosure that corporations should undertake with an intention that each sovereign government should adopt these recommendations (Gray \& Bebbington). As per such recommendations a company should disclose following information in the directors reports.

\# Environmental issues pertinent to the company and industry.

\# Environmental policy adopted.

\# Improvements made since adopting the policy

\# Enterprise's environmental emission targets and performance against these.

\# Response to government legislation.

\# Material environmental protection measures on capital investment and earnings.

\# Material costs charged to current operations.

\# Material amounts capitalised in the periods.

In addition to that company should disclose some other information in the notes to the financial statement. Such information are:

\# The accounting policies for recording liabilities and provisions, for setting up catastrophe reserves and for disclosing contingent liabilities.

\# Amount of liabilities, provisions, reserve established in the period.

\# Amount of contingent liabilities.

\# Tax effects.

\# Government grants received in the period.

Further the United Nations Commission for Transnational Corporations Intergovernmental Working Group of Experts on International Standards of Accounting and Reporting (UN-IASR) have issued certain guidelines for identification, recognition, measurement and communication of environmental cost and liabilities within the framework of financial accounting. The following is the draft of UN-IASR guidelines on environmental financial accounting adopted in July 1997.

\# Recognition of environmental costs:

- Environmental costs relating to damage should be recognised immediately and charged to income.

- Environmental cost should only be capitalised if they meet the specific criteria.

- Future site restoration costs should be accrued and capitalised as the damage is incurred.

- Environmental costs which are part of an asset should be included with that asset.

- Environmental cost that does not meet the assets recognition criteria should be expensed immediately. \# Recognition of environmental liabilities:

- An environmental liability should be recognised when the enterprise is obliged to incur an environmental cost and cannot avoid that cost.

- Environmental damage- even when there is no immediate duty to remediate- should be disclosed in the notes to the accounts.

- Costs relating to the remediation or removal of long lived assets should be recognised as liability at the time of damage. 
\# Recognition of recoveries

- Recovery expected from a third party should not been netted off but separately recorded.

- $\quad$ Expected sale of property should not be netted of against environmental liability.

\#Measurement:

- Best practice should be used to estimate liabilities and where this is not possible this must be explain in the notes to the accounts.

- Net present value may be used to estimate certain liabilities and this should be disclosed. \# Disclosure:

- The enterprise should separately disclosed:

-Its categories of environmental costs.

-Environmental costs charged to income.

-Fine and penalties

-Environmental liabilities with accompanying details.

These guidelines are vanguard to develop thinking on how to approach the regulation of accounting and environmental issues. It gives impetus for the professional accounting bodies to develop their own standard in environmental accounting issue.

Many countries of the world and their accounting professional and standard setting bodies like in USA (AICPA), Canada (CICA), UK (ACCA, ICAEW, ICAS), the Netherlands (NIVRA), Australia (ICAA), etc. and international bodies such as IFAC, IASB and, especially, FEE in Europe are seem to be active in environmental accounting issue. Few countries like Denmark, Netherlands, Norway, and Sweden have made environmental disclosures mandatory in business reporting. However, accounting standard setting bodies are still (generally) reluctant to address environmental matters as a separate, stand-alone issue, their pronouncements of such matters is as provisions, liabilities, impairment of fixed assets and so on increasingly reflect recognition of and concern about the impact of environmental matters.

\section{Environmental Accounting framework in India:}

Indian civilization has a long tradition of taking care of environment. In the constitution under the 'Directive principle of state policy' it is expressly mentioned that it is the duty of the state 'to protect and improve the environment and to safeguard the forest and wildlife of the country.' It is the fundamental duty of every citizen of India 'to protect and improve the natural environment including forest, lakes, rivers and wildlife.' Government of India enacted numbers of laws which can directly and indirectly help the protection of environment and natural resources. In addition to that Union Ministry of Environment and Forest and corresponding state governments have made a provision for environmental clearance before any industrial unit actually set up. However, there is no any specific guideline regarding accounting and disclosure of environmental cost and liabilities except provisions of company about disclosure of conservation of energy, technology absorption in directors' report under sec 217(1). Recently Ministry of corporate affairs laid more emphasis on corporate social responsibility and accordingly issued National Voluntary Guidelines on Social Environmental and Economic Responsibility of the business in 2011. In such guidelines, principle 2 mentions that business should provide goods and service that are safe and contribute to sustainability throughout their life cycle. Again in the principle 6, it is explicitly mentioned that Business should respect, protect and make efforts to restore environment. In pursuance of that a business should report:

- Percentage of materials used that are recycled input materials

- Total energy consumed by the business entity for its operations

- Statement on use of energy saving processes and the total energy saved due to use of such processes

- Use of renewable energy as percentage of total energy consumption

- Total water consumed and the percentage of water that is recycled and reused

- Statement on quantum of emissions of greenhouse gases and efforts made to reduce the same

- Statement on discharge of water and effluents indicating the treatment done before discharge and the destination of disposal

- Details of efforts made for reconstruction of bio-diversity.

The disclosures of above mentioned information are voluntary and there are no specific guidelines on format of reporting. On the other hand accounting standard board and Ministry of Corporate Affairs is till silent on environmental accounting and disclosure issue in corporate accounting and reporting.

\section{Environmental accounting and Reporting practices in India:}

From the study of annual reports of the sample companies it has been evident that Indian corporate bodies are very much sensitive in the environmental issue. They want report about their environmental care to the stakeholder. All the sample companies have reported their environmental initiatives in their annual reports in addition to their mandatory disclosures as required by the Companies Act. However, important fact is that the 
place of reporting is not uniform. Companies have reported such information either in the directors' report, in separate sustainability report, in management discussion and analysis report or any one of them. Table 1 reflects the distribution of environmental reporting of the sample companies. From the study, it reveals that $25 \%$ of sample companies reported such information only in the directors' report. 25\% of the sample companies reported only in separate sustainability report. Contrary to that $16.66 \%$ of the sample companies reported such information in directors' report and management discussion \&analysis report and $25 \%$ of sample companies reported environmental information in directors' report as well as separate sustainability report. Again few companies used to report such information in all of above sections. Study reveals that $8.33 \%$ of the sample companies reported such information in directors' report, management discussion \&analysis and separate sustainability report. Such variation in the format of reporting may distort the utility of the information as it leads to spreading of information and in many cases there is repetition of information.

Table 1

Place of environmental reporting

\begin{tabular}{|l|c|}
\hline \multicolumn{1}{|c|}{ Place of reporting } & No of companies \\
\hline 1.only in directors report & $3(25 \%)$ \\
\hline 2. In separate sustainability report & $3(25 \%)$ \\
\hline 3.Only in management discussion \& analysis & nil \\
\hline 4. In directors report and management discussion \&analysis & $2(16.66 \%)$ \\
\hline 5. In separate sustainability report and directors report & $3(25 \%)$ \\
\hline 6. In directors report, management discussion \&analysis and sustainability report & $1(8.33 \%)$ \\
\hline Total & $12(100 \%)$ \\
\hline
\end{tabular}

Source: Annual reports

\section{Themes of information reported:}

The growing awareness among the stakeholder about environment and global development of environment disclosures leads the company to disclosure of environmental initiative in addition to the compliance of mandatory requirement. In such disclosures it has been noticed that conservation and management of water is one of important issue. Study reveals that $75 \%$ of the sample companies disclosed their effort for conservation of water. Under this area they reported their efforts about recycling and reuse of water, recharge of ground water by rain water harvesting and by reduction of water consumption. Energy consumption is one of important issue for business. Due to consumption of energy, not only the energy reserve of the earth is sinking but also it contributes to environmental degradation. The solution to that lies on the reduction of energy consumption and use of renewable source of energy. $58.33 \%$ of the sample companies reported about their effort to generation of renewable source of energy like wind energy, bio-diesel etc. Only few sample companies includes information about amount of such power generated by the company. This gives ample evidence about their environmental consciousness. Another important issue in the environmental degradation is the waste management. Business unit generally generate more waste, hence proper management of waste is necessary to protect the environment. 50\% of the sample unit has reported about their effort to management of waste by reduction, recycling and reuse of waste. Deforestation is one of the important issues for environmental imbalance. Due to establishment of industrial unit, green coverage has been sinking which may be one of the causes of ecological imbalances. It is the duty of business to spend some amount of revenue to create and conserve the green belt. It comes to light that $50 \%$ of sample unit has reported that they made effort to increase the green belt and conservation of bio-diversity. However, such information does not include amount of money spent for such initiatives. Another important issue of environmental degradation is global warming. The global warming has been increasing due to emission of green house gas. The study reveals that $75 \%$ of the sample unit has reported about their effort to reduction of emission level as their environmental initiatives. Most of the companies reported that they made effort to reduce emission level with improvement of production process and use of improved technology. It is noted that such reports grossly neglect to report the current level and previous level of emission data. Table 2 depicts a summary of the environmental accounting and reporting themes used by the sample units.

Table: 2

Themes of information Reported:

\begin{tabular}{|l|c|}
\hline \multicolumn{1}{|c|}{ Nature of information } & No of companies \\
\hline 1. water preservation / recycling & $9(75 \%)$ \\
\hline 2.Generation of renewable source of energy & $7(58.33 \%)$ \\
\hline 3. waste management and recycling & $6(50 \%)$ \\
\hline 4. bio-diversity conservation and generation of green belt & $6(50 \%)$ \\
\hline 5. Effort to reduce green house gas & $8(75 \%)$ \\
\hline
\end{tabular}

Source: Annual report 
From the analysis of the environmental accounting and reporting practices in India it is clear that Indian companies are used to disclose environmental protection effort in their annual report. However, there is a wide variation in respect of the place of report and the theme selected for report. Another important fact is that the most of the information are non-quantitative in nature. Only few sample companies express quantitative disclosures i.e. percentage of reduction of carbon footprint and emission of green house gas in comparison to previous year. It is also pertaining to note that no information has been found in the annual report about recognition of environmental expenses and liability in financial information of the business. Moreover, such initiatives may have financial implication which may be positive or negative, but it should be properly recognised in the financial information to have a true and fair of financial results and state of affairs of the business. Again if any corporate body has already policy of recognition of such with financial results it should have proper disclosures in the note to the accounting and accounting policy. But such information is not found in the accounting and reporting practices of the sample units.

Considering the present state of environmental accounting and reporting practice used by corporate bodies one cannot conclude that the present state of environment accounting is useful to users to make an assessment about involvement of corporate bodies on environment protection as such information are not verifiable and also it does not properly reflected in financial information of the business.

\section{Challenges for environmental Accounting and reporting:}

Environmental accounting is very important issue. As economic development as well as environmental protection is equally important but contradictory issue therefore a careful assessment of the benefits and costs of environmental damages is necessary to find the tolerance limit of environmental degradation and the required level of development. For that there is need for proper framework which can provide guidelines on the issue of environmental cost, environmental liability, environmental assets, capitalisation of such cost and liability and reporting framework. Again environmental costs have impact on reported profit in the financial statement as well as product pricing. Study of corporate reporting practices reflects that there is an increasing tendency among the corporate managers to disclose some information in their annual report to inform about their efforts to shareholders and public in general. It is also clear that most of such environmental information reported by the companies is found to be non-financial. Such information is mere description of the efforts made by the company. The information on amount of money spent for such initiatives and its material effect on financial results is grossly missing in such information. Again there is wide variation noticed in the style of reporting and theme the companies selected to report. This can add to other dimension of the problem of lack of comparability and verifiability. So it is felt that such information should be integrated with financial accounting information to have reliability. For integration it is necessary for monetary measurement of environmental cost and benefits. But all cost and benefit to the environment cannot be suitably measured in monetary unit, at least at micro level. Internal cost, like investment made by the corporate sector for minimization of losses to Environment by product development, process development can be possible for monetary measurement but cost of externalities like degradation and destruction like soil erosion, loss of bio diversity, air pollution, water pollution, noise pollution, problem of solid waste, depletion of nonrenewable natural resources i.e. loss emerged due to over exploitation of non-renewable natural resources like minerals, water, gas, deforestation etc. and the environmental assets created by business like afforestation, bio-diversity conservation, water preservation etc cannot be suitably measured in monetary terms. Further, it is very hard to decide that how much loss has occurred to the environment due to establishment of a specific business unit. This makes obstacles in the total integration of environmental accounting within the framework of existing GAAP. However, it is possible to disclose internal cost and benefit of environmental measures that is undertaken by a business unit and its material effects in reported profit by disclosing the way of recognition. In case of externalities, like level emission, waste generation, afforestation etc. though monetary assessment is not possible but business can make some sort of quantitative measurement like for water management cubic kilometres, for emission level concentration of specified particles in terms of ppm., area of land afforested, quantitative facts on expenditures incurred of such activities, and targets set and achieved. This kind of information can enhance authenticity and reliability of environmental information. However, for such kind of assessment involvement of some technicalities is necessary. On the other hand for such recognition of inter cost and other externalities a specific set of regulatory pronouncement is pre-requisite to have uniformity of accounting information. As in the present state environmental accounting and reporting is a voluntary rather than mandatory, in such situation everyone have tendency to depict the strength rather than the weakness.

\section{Conclusion:}

Corporate reporting is one of important vehicle for the corporate bodies to communicate with external world. With the increases of the complexities of the business world the role of information has been gradually increasing for making economic decision. It is also recognised fact that due to increase in level of environmental 
awareness of stakeholder, environmental reporting now becomes a part of financial reporting in India. Most of the Indian companies use to report environmental initiative in their annual report. However, such reporting is mere descriptive and nothing is disclosed about its financial implications and accounting policy of environmental cost. It is not possible to measure all environmental liabilities (bad) and Assets (good) in monetary unit. As result it is not possible to integrate all environmental information with existing accounting system at micro level. However, it can be concluded that the internal cost of environment to a firm which have material effect on financial results of the business can be suitably integrated with existing accounting information. For externalities it is possible to have some other quantitative measurement and disclosure. Moreover, due to absence of clear guideline of accounting regulatory bodies, like accounting standard board, Ministry of Corporate affairs etc. on the issue like environmental cost, environment assets and liabilities, recognition and measurement of such cost, assets and liabilities and its disclosure requirement, it is not developed as it is expected by stakeholder. The recent initiative of Ministry of Corporate Affairs(MCA) of the Government of India, i.e. the 'National Voluntary Guidelines on Social Environmental and Economic Responsibility of the business $2011^{\prime}$ 'is also in infant stage. Thus it can be concluded that, though environment reporting has been developed in the corporate reporting practices in India, it is found to be lack of comparability and verifiability, the basic characteristics of accounting information. So it is expected that in the near future the government and other accounting regulatory bodies will play more active role in the development of environmental accounting and reporting by making it reliable and relevant to users.

\section{References:}

[1]. Ahmad, N. N. N., \& Sulaiman, M. (2004). Environmental disclosures in Malaysian annual reports: A legitimacy theory perspective. International Journal of Commerce and Management, 14(1), 41-57

[2]. Banerjee Dr. Bhabatosh(2006) : Corporate Environmental Accounting and Reporting : The Chartered Accountant :April

[3]. Bhate,S (2002): one world, one environment, one vision: Are we close to achieve this? An Explanatory Study of Consumer Environmental Behaviour across three countries. Journal of consumer Behaviour,2(2), 169-184.

[4]. Chauhan Dr. Mukesh (2005) : Concept of Environmental Accounting and Practice in India The Chartered Accountant(November 2005)

[5]. Chatterjee, B., \& Mir, M. Z. (2008): The current status of environmental reporting by Indian companies. Managerial Auditing Journal, 23(6), 609-629. http://dx.doi.org/10.1108/02686900810882138

[6]. Gupta S. K. and Mehra A (2002):., Contemporary Issues in Accounting, , Kalyani Publishers, Ludhiana

[7]. Halil Emre Akbas \& Seda Canikli(2014): Corporate Environmental Disclosures in a Developing Country: An Investigation on Turkish Listed Companies: International Journal of Economics and Finance; Vol. 6, No. 2;

[8]. Pramanik, A. K. (2002), Environmental Accounting and Reporting (eds.), , Deep \& Deep publications Pvt. Ltd: New Delhi.

[9]. Pramanik,A.K. Shil Nikhil Chandra \& Das Bhagaban (2008): Corporate environmental Reporting : An Emerging issue in the Corporate world: International Journal of Business and Management, vol 3, no12, 146-154.

[10]. Paul, K.C and Pal,B.(2001): Corporate Environmental Reporting in India. Indian Accounting Review, (December),27-45.

[11]. Rahman, M. A. and Muttakin, M. B. (2005). Corporate Environmental Reporting Practices in Bangladesh - A Study of Some Selected Companies. The Cost \&Management, 33(4), 13-21.

[12]. Rob Gray \& Jan Bebbington (2001) : Accounting for the Environment: SAGE Publications Ltd: London

[13]. Sajad Gholami, Ayat Tamri Neia, Behzad Gohari, Bahman Kiani Rad(2013): Environmental Accounting (From Concept to Practice): Journal of Basic and Applied Scientific Research. 3(1)439-443.

[14]. Shukla Dr. Anita \&, Nidhi Vyas (2013): Environmental Accounting \& Reporting in India (A comparative study of Bharat Petroleum Company Limited \& Oil \& Natural Gas Company Limited): Pacific Business Review International:Volume 5 Issue 7 (January 2013)

[15]. Thomas p. lyon and John w. Maxwel (2004): Corporate Environmentalism and Public Policy: Cambridge University Press. Reports:

[16]. COM (92) 23, Vol. II, Towards Sustainability, from DG XI, reported in World Accounting Report, May 1992 , p. 1.

[17]. Environmental Accounting Guidelines (2005): Ministry of the Environment Japan, February 2005

[18]. Environmental Financial Accounting and Reporting at the Corporate Level: A Report of UNCTAD Secretariat, Fifteenth session Geneva, 11-13 February 1998

[19]. National Voluntary Guidelines on Social Environmental \&Economic Responsibilities of Business (2011): Ministry of Corporate Affairs, Government of India. 